\title{
PENGEMBANGAN PERANGKAT PEMBELAJARAN FISIKA MODEL INKUIRI TERBIMBING BERBANTUAN LABORATORIUM VIRTUAL UNTUK MENINGKATKAN KETERAMPILAN BERPIKIR KREATIF PESERTA DIDIK
}

\author{
Raka Panji Satria'1), Hairunisyah Sahidu(1), Susilawati1) \\ 1)Program Studi Pendidikan Fisika, FKIP, Universitas Mataram, Mataram, NTB, Indonesia \\ Corresponding author : Raka Panji Satria \\ E-mail : rakapanjisatria@gmail.com
}

Diterima 19 Oktober 2020, Direvisi 01 November 2020, Disetujui 02 November 2020

\begin{abstract}
ABSTRAK
Penelitian pengembangan ini bertujuan untuk menghasilkan produk berupa perangkat pembelajaran model inkuiri terbimbing berbantuan laboratorium virtual untuk meningkatkan keterampilan berpikir kreatif peserta didik. Jenis penelitian adalah Research and Development (R\&D) dengan model 4D terdiri dari Define, Design, Develop, dan Disseminate. Produk yang dikembangkan berupa silabus, rencana pelaksanaan pembelajaran daring, lembar kerja peserta didik, dan instrumen tes keterampilan berpikir kreatif. Validitas produk dinilai oleh enam validator dengan analisis skala likert. Selanjutnya kepraktisan ditentukan dari hasil observasi melalui lembar keterlaksanaan kegiatan dan efektivitas diperoleh dari uji coba terbatas untuk mendapatkan nilai $\mathrm{N}$-gain. Hasil penelitian berdasarkan penilaian validator menunjukkan keseluruhan perangkat yang dikembangkan memiliki nilai rata-rata diatas 3.26 dengan kategori sangat baik. Kemudian hasil observer menunjukkan rata-rata keterlaksanaan kegiatan diatas $63 \%$ dengan kategori sangat baik. Lalu hasil rata-rata uji $\mathrm{N}$-gain didapatkan nilai 0.51 dengan kategori sedang. Sehingga dapat disimpulkan perangkat pembelajaran fisika model inkuiri terbimbing berbantuan laboratorium virtual pada materi elastisitas dan hukum Hooke valid, praktis, dan efektif untuk meningkatkan keterampilan berpikir kreatif peserta didik.
\end{abstract}

Kata kunci: perangkat pembelajaran; model inkuiri terbimbing; laboratorium virtual; keterampilan berpikir kreatif.

\begin{abstract}
This development research aims to produce products in the form of guided inquiry learning models assisted by virtual laboratories to improve students' creative thinking skills. The type of research is Research and Development (R\&D) with a 4D model consisting of Define, Design, Develop, and Disseminate. Products developed in the form of a syllabus, online lesson plans, student worksheets, and creative thinking skills test instruments. The validity of the product is limited by six validators with Likert scale analysis. Furthermore, practicality is determined from the results of observations through the implementation sheet and can be obtained from limited trials to get the $\mathrm{N}$-gain score. The results of the research based on the facts of the validator showed that the total developed equipment had an average value above 3.30 with the very good category. Then the results of the observers showed that the average activity implementation was above $75 \%$ with the very good category. Then the results of the average $\mathrm{N}$-gain test obtained a value of 0.51 in the medium category. So it can be concluded that the guided inquiry model physics learning device with virtual assistance on elasticity material and Hooke's law is valid, practical, and effective for improving students' creative thinking skills.
\end{abstract}

Keywords: learning tools; guided inquiry model; virtual laboratory; creative thinking skills.

\section{PENDAHULUAN}

Pandemi Covid-19 membuat seluruh sektor kehidupan manusia terganggu, termasuk dalam bidang pendidikan. Pembelajaran yang biasanya dilakukan secara tatap muka terpaksa dilakukan secara daring untuk mencegah penularan. Guru sebagai pendidik harus dapat merubah strategi pembelajaran dengan mengedepankan kurikulum 2013 yang menekankan keaktifan peserta didik ditengah pandemi. Selain itu, implementasi kurikulum 2013 diharapkan juga dapat mengembangkan keterampilan berpikir tingkat tinggi atau High Thingking Skill Order (HOTS) khususnya pada keterampilan berpikir kreatif guna meningkatkan kualitas lulusan yang dapat bersaing di era globalisasi. Oleh karena itu dibutuhkan suatu model pembelajaran yang dapat membangkitkan kreatifitas dengan memberikan kesempatan peserta didik untuk 
berperan aktif dalam pembelajaran. Salah satu model yang dapat digunakan adalah model pembelajaran inkuri terbimbing.

Inkuiri berasal dari bahasa inggris berarti pertanyaan atau penyelidikan. Menurut Bell et al (2010) inkuiri terbimbing merupakan model pembelajaran yang dapat melatih keterampilan peserta didik dalam melaksanakan proses investigasi untuk mengumpulkan data berupa fakta dan memproses fakta tersebut sehingga peserta didik mampu membangun kesimpulan secara mandiri guna menjawab pertanyaan atau masalah yang diajukan oleh guru dengan menemukan sendiri solusi dari permasalahan maka pembelajaran bermakna akan tercipta karena peserta didik mengalami sendiri dalam memecahkan persoalan melalui pengalaman. Tetapi, dalam pelaksanaan pembelajaran menggunakan model ini memerlukan media untuk melakukan penyelidikan atau praktikum. Salah satu media yang dapat digunakan adalah laboratorium virtual.

Laboratorium virtual (virtual laboratory) merupakan pemanfaatan media komputer yang telah dirancang sedemikian rupa sebagai sarana dilakukannya simulasi secara visualisasi untuk menggantikan setiap percobaan praktikum di laboratorium nyata Rina Mirdayanti \& Murni (2017). Salah satu laboratorium virtual yaitu PhET Simulation Interactive yang berisi simulasi percobaan untuk kepentingan pembelajaran di kelas maupun belajar individu. Simulasi percobaan dalam PhET Simulation mudah untuk digunakan dan hasil yang didapat serupa dengan percobaan riil. Oleh karena itu, laboratorium virtual ini sangat tepat digunakan dalam pembelajaran daring sebagai alternatif untuk melaksanakan praktikum di rumah. Penelitian yang telah dilakukan sebelumnya, penggunaan model pembelajaran inkuiri terbimbing dan laboratorium virtual memberikan dampak positif terhadap peserta didik.

Berdasarkan penelitian yang dilakukan oleh Sintya et al (2018), Detagory et al (2017), dan Putra et al (2016) menyatakan penggunaan model pembelajaran inkuiri terbimbing dapat meningkatkan kemampuan berpikir kreatif peserta didik. Selain itu, penelitian Yolanda et al (2019) menyatakan penggunaan model pembelajaran inkuiri terbimbing berbantuan laboratorium virtual membantu peserta didik dalam meningkatkan penguasaan konsep. Sintak model pembelajaran inkuiri terbimbing dimodifikasi berdasarkan pendapat Trianto (2011) dengan menambahkan laboratorium virtual sehingga terbentuk 6 (enam) fase yakni menyajikan masalah, membuat hipotesis, mendesain percobaan virtual, melakukan percobaan virtual untuk memperoleh data, mengumpulkan dan menganalisis data virtual, dan membuat kesimpulan.

Berdasarkan hasil observasi yang dilakukan peneliti di SMAN 6 Mataram terdapat berbagai permasalahan pada pembelajaran fisika yaitu keterlibatan peserta didik masih sangat kurang, pembelajaran masih berpusat pada guru, peserta didik cenderung pasif sehingga mengalami kesulitan terutama dalam mengembangkan kreatifitas. Berdasarkan wawancara, pelaksanaan kurikulum 2013 kurang maksimal karena jarang dilakukan praktikum disebabkan peralatan yang kurang. Hal ini membuat guru jarang membuat LKPD khusus untuk satu materi. Pembelajaran seperti ini diduga mempengaruhi keterampilan berpikir kreatif. Selain itu, guru belum terlalu mengenal model pembelajaran inkuiri terbimbing sehingga model ini menjadi sesuatu hal yang baru.

Oleh karena itu dibutuhkan pengembangan perangkat pembelajaran fisika berbasis model pembelajaran inkuiri terbimbing berbantuan laboratorium virtual untuk meningkatkan keterampilan berpikir kreatif peserta didik. Adapun perangkat yang dikembangkan adalah silabus, rencana pelaksanaan pembelajaran (RPP) daring, lembar kerja peserta didik (LKPD), dan soal keterampilan berpikir kreatif

\section{METODE PENELITIAN}

Jenis penelitian yang akan digunakan adalah penelitian pengembangan atau Reasearch and Development (R\&D) dengan 4D Models atau 4 tahapan utama menurut Sugiyono (2013), yaitu pendefinisian (Define), perancangan (Design), pengembangan (Develop); dan diseminasi (Disseminate) dengan subjek penelitian yaitu peserta didik SMAN 6 Mataram Kelas XI IPA 3 tahun ajaran 2020/2021 yang terdiri dari 34 orang. Teknik pengumpulan data menggunakan lembar validasi dengan skala likert 1-4 yang akan dinilai oleh enam validator ahli yang terdiri dari tiga dosen dan tiga guru praktisi. Selanjutnya, dilakukan ujicoba perangkat dalam pembelajaran yang akan diobservasi oleh tiga observer untuk melihat kepraktisan perangkat dan dilakukan pre-test dan pos-test untuk mendapatkan nilai $\mathrm{N}$-gain demi menentukan keefektifan perangkat.

Analisis validitas instrumen dan perangkat pembelajaran berbasis model pembelajaran inkuiri terbimbing berbantuan laboratorium virtual dicari dengan menggunakan persamaan.

Skor penilaian $=\frac{\text { jumlah skor pada instrumen }}{\text { Jumlah skor instrumen }} \times 4$ 
Dengan skor penilaian intrumen dikonversi menjadi beberapa tingkat kelayakan pada tabel 1 sebagai berikut.

Tabel 1 Tingkat Kelayakan Instrumen

\begin{tabular}{lll}
\hline $\begin{array}{l}\text { Skor } \\
\text { Penilaian }\end{array}$ & $\begin{array}{l}\text { Rerata } \\
\text { Skor }\end{array}$ & Klasifikasi \\
\hline $\mathbf{4}$ & $3,26-4,00$ & Sangat Baik \\
\hline $\mathbf{3}$ & $2,51-3,25$ & Baik \\
\hline $\mathbf{2}$ & $1,76-2,50$ & Kurang Baik \\
\hline $\mathbf{1}$ & $1,01-1,75$ & Tidak Baik \\
\hline \multicolumn{2}{r}{ (Pangestika et al., 2013) }
\end{tabular}

Analisis keterlaksanaan kegiatan pembelajaran digunakan untuk mengetahui kepraktisan perangkat yang dikembangkan dengan melihat apakah semua kegiatan dapat terlaksana serta keruntutan pembelajaran. Analisis ini ditentukan dari skor pengisian lembar observasi oleh observer, kemudian dianalisis dengan menghitung Interjudge Agreement (IJA) dengan cara:

$$
I J A=\frac{A y}{A y+A N} \times 100 \%
$$

(Arsanty \& Wiyatmo, 2017)

Dengan

Ay : kegiatan yang terlaksana

AN : kegiatan yang tidak terlaksana

Tabel 2 Kriteria Kepraktisan Perangkat

\begin{tabular}{cc}
\hline Interval & Kriteria \\
\hline$I J A>63$ & Sangat Baik \\
\hline $51<I J A \leq 63$ & Baik \\
\hline $39<I J A \leq 51$ & Cukup Baik \\
\hline $27<I J A \leq 39$ & Kurang Baik \\
\hline$I J A \leq 27$ & Sangat Kurang \\
\hline
\end{tabular}

(Santi \& Santosa, 2016)

Peningkatan keterampilan berpikir kreatif peserta didik dapat ditentukan dengan menggunakan Standar Gain dengan persamaan berikut:

Dimana

$$
\text { Std }<g>=\frac{\bar{X}_{\text {sesudah }}-\bar{X}_{\text {sebelum }}}{\bar{X}_{\text {maks }}-\bar{X}_{\text {sebelum }}}
$$

$$
\begin{array}{ll}
\bar{X}_{\text {sesudah }} & : \text { skor post-test } \\
\bar{X}_{\text {sebelum }} & : \text { skor pre-test } \\
\bar{X}_{\text {maks }} & : \text { skor maksimum } 100
\end{array}
$$

Berdasarkan hasil yang diperoleh dengan menggunakan Standar Gain, dikelompokkan kategori keterampilan berpikir kreatif peserta didik berdasarkan tabel 3 berikut.

Tabel 3 Interpretasi Indeks $\mathrm{N}$-Gain

\begin{tabular}{ll}
\hline $\boldsymbol{N}$-Gain Score $(\mathbf{g})$ & Kategori \\
\hline $0,70<\mathrm{g}<1,00$ & Tinggi \\
$0,30<\mathrm{g}<0,70$ & Sedang \\
$0,0<\mathrm{g}<0,30$ & Rendah \\
\hline
\end{tabular}

(Sundayana, 2014)

\section{HASIL DAN PEMBAHASAN \\ 1. Tahap Define (pendefinisian)}

Tahap define diartikan tahap penetapan syarat-syarat pembelajaran. Tahap ini terdiri dari analisis awal, analisis tugas, analisis spesifikasi tujuan pembelajaran. Pada analisis awal terdapat beberapa permasalahan yaitu peserta cenderung pasif dan pembelajaran terjadi hanya satu arah membuat peserta didik kurang kreatif. Dalam pembelajaran daring, permasalahan yang dialami yaitu peserta didik tidak memiliki kuota internet, alhasil penyampaian materi tidak optimal. Pada analisis tugas, materi yang digunakan adalah elastisitas dan hukum Hooke yang selanjutnya dilakukan dibuat tujuan pembelajaran.

\section{Tahap Design (perancangan)}

Tahap design merupakan tahap merancang draft awal perangkat pembelajaran yang akan digunakan dalam materi Elastisitas dan Hukum Hooke. Perangkat pembelajaran berbasis model inkuiri terbimbing berbantuan laboratorium virtual. Adapun draft yang dihasilkan berupa silabus, RPP, LKPD, dan soal keterampilan berpikir kreatif

\section{Tahap Development (Pengembangan)}

Tahap development merupakan tahap untuk menghasilkan produk pengembangan yang dilakukan melalui dua langkah, yaitu uji validasi produk oleh validator ahli terdiri dari tiga dosen dan tiga guru praktisi serta uji coba secara terbatas pada kelas XI IPA 3. Hasil penilaian perangkat validator sebagai berikut.

Tabel 4 Penilaian Perangkat Oleh Validator

$$
\text { Dosen }
$$

\begin{tabular}{ccc} 
Perangkat & $\begin{array}{c}\text { Nilai Rata-rata } \\
\overline{\overline{\boldsymbol{X}}}\end{array}$ & Kategori \\
\hline Silabus & 3.83 & Sangat Baik \\
\hline RPP & 3.65 & Sangat Baik \\
\hline LKPD & 3.57 & Sangat Baik \\
\hline Soal KBK & 3.61 & Sangat Baik \\
\hline
\end{tabular}

Tabel 5 Penilaian Perangkat Oleh Validator Guru

\begin{tabular}{ccc}
\hline Perangkat & $\begin{array}{c}\text { Nilai Rata-rata } \\
\overline{\boldsymbol{X}}\end{array}$ & Kategori \\
\hline Silabus & 3.79 & Sangat Baik \\
\hline RPP & 3.75 & Sangat Baik \\
\hline LKPD & 3.83 & Sangat Baik \\
\hline Soal KBK & 3.89 & Sangat Baik \\
\hline
\end{tabular}

Dari tabel 3 dan 4 nilai rata-rata perangkat baik dari validator dosen maupun guru sama-sama menunjukkan nilai diatas 3.26 dengan keseluruhan berkategori sangat baik. Selanjutnya, hasil observasi keterlaksanaan kegiatan pembelajaran yang dilakukan oleh tiga observer untuk melihat kepraktisan perangkat sebagai berikut. 
Tabel 6 Keterlaksanaan Kegiatan Pembelajaran

\begin{tabular}{lllll}
\hline Pertemuan & \multicolumn{3}{c}{ Presentase } & $\overline{\boldsymbol{X}}$ IJA \\
& \multicolumn{2}{c}{ Keterlaksanaan (\%) } & (\%) \\
\cline { 2 - 4 } & Obs 1 & Obs 2 & Obs 3 & \\
\hline $\mathbf{1}$ & 94.44 & 94.44 & 83.33 & 90.74 \\
\hline $\mathbf{2}$ & 94.44 & 100.00 & 88.89 & 94.44 \\
\hline $\mathbf{3}$ & 100.00 & 88.89 & 83.33 & 90.74 \\
\hline
\end{tabular}

Tabel 6 menunjukkan rata-rata skor IJA diatas $63 \%$ dengan kategori sangat baik. Terakhir, dilakukan pre-test dan pos-test untuk memperoleh nilai $\mathrm{n}$-gain dengan hasil sebagai berikut.

Tabel 7 Hasil Uji N-gain

\begin{tabular}{ccc}
\hline $\bar{X}$ Pretest & $\bar{X}$ Postest & $N-$ Gain \\
\hline 7.84 & 54.66 & 0.51 \\
\hline
\end{tabular}

Berdasarkan tabel 7 , nilai $\mathrm{N}$-gain yang diperoleh yakni 0.51 dengan kategori sedang.

\section{Tahap Disseminate (Penyebarluasan)}

Tahap Disseminate merupakan tahap akhir dalam penelitian ini. Pada tahap ini peneliti menyebarkan hasil penelitian berupa artikel ilmiah yang telah di submit pada $e$ journal.

\section{SIMPULAN}

Perangkatkan pembelajaran yang dikembangkan valid, praktis, dan efektif untuk meningkatkan keterampilan berpikir kreatif peserta didik.

\section{DAFTAR RUJUKAN}

Arsanty, V. N., \& Wiyatmo, Y. (2017). Pengembangan Perangkat Pembelajaran Fisika Berbasis Model Pembelajaran STS dalam Peningkatan Penguasaan Materi dan Pencapaian Kreativitas Peserta Didik SMA. Jurnal Pendidikan Fisika, 6(1), 2332.

Bell, T., Urhahne, D., Schanze, S., \& Ploetzner, R. (2010). Collaborative inquiry learning: Models, tools, and challenges. International Journal of Science Education, 32(3), 349-377.

Detagory, W. N., Hanurawan, F., \& Mahanal, S. (2017). Peran Model Pembelajaran Inkuiri Terbimbing Dalam Kemampuan Bepikir Kreatif Siswa Pada Pembelajaran IPA Di SD. In Transformasi Pendidikan Abad 21 (Vol. 6, pp. 926-933).

Pangestika, M. W., Suyanto, E., \& Viyanti. (2013). Pengembangan Lembar Kerja Siswa Berbasis Keterampilan Proses Sains pada Kompetensi Dasar Menyelidiki Sifat-Sifat Zat Berdasarkan Wujudnya dan Penerapannya dalam Kehidupan SehariHari. Jurnal Pembelajaran Fisika, 1(1),
$55-65$.

Putra, R. D., Rinanto, Y., Dwiastuti, S., \& Irfa, I. (2016). Peningkatan Kemampuan Berpikir Kreatif Siswa melalui Model Pembelajaran Inkuiri Terbimbing pada Siswa Kelas XI MIA 1 SMA Negeri Colomadu Karanganyar Tahun Pelajaran 2015 / 2016. Proceeding Biology Education Conference, 13(1), 330-334.

Rina Mirdayanti, \& Murni. (2017). Kajian Penggunaan Laboratorium Virtual Berbasis Simulasi Sebagai Upaya Mengatasi Ketidak-Sediaan Laboratorium. Visipena Journal, 8(2), 323-330.

Santi, I. K. L., \& Santosa, R. H. (2016). Pengembangan Perangkat Pembelajaran Menggunakan Pendekatan Saintifik pada Materi Pokok Geometri Ruang SMP. PYTHAGORAS: Jurnal Pendidikan Matematika, 11(1), 35-44.

Sintya, W. K., Purwanto, A., \& Sakti, I. (2018). Penerapan Model Pembelajaran Inkuiri Terbimbing Untuk Meningkatkan Kemampuan Berpikir Kreatif Siswa di SMAN 2 Kota Bengkulu. Jurnal Kumparan Fisika, 1(3), 7-12.

Sugiyono. (2013). Metode Penelitian Kuantitatif, Kualitatif, dan R\&D. Bandung: Alfabeta.

Sundayana, R. (2014). Statistika Penelitian Pendidikan. Bandung: Alfabeta.

Trianto. (2011). Mendesain Model Pembelajaran Inovatif-Progresif. Jakarta: Kencana.

Yolanda, S. E., Gunawan, G., \& Sutrio, S. (2019). Pengaruh Model Pembelajaran Inkuiri Terbimbing Berbantuan Video Kontekstual Terhadap Penguasaan Konsep Fisika Peserta Didik. Jurnal Pendidikan Fisika Dan Teknologi, 5(2), 341. 